Article

\title{
Crosstalk between PPAR $\gamma$ Ligands and Inflammatory-Related Pathways in Natural T-Regulatory Cells from Type 1 Diabetes Mouse Model
}

\author{
S. Zulkafli Nor Effa ${ }^{1,2, *}$, Nik Soriani Yaacob ${ }^{3}$ (D) and Mohd Nor Norazmi ${ }^{1, *}$ \\ 1 School of Health Sciences, Universiti Sains Malaysia, Kelantan, Kubang Kerian 16150, Malaysia \\ 2 Regenerative Medicine Cluster, Advanced Medical and Dental Institute (AMDI), Universiti Sains Malaysia, \\ Bertam, Kepala Batas 13200, Malaysia \\ 3 School of Medical Sciences, Universiti Sains Malaysia, Kelantan, Kubang Kerian 16150, Malaysia; \\ niksoriani@usm.my \\ * Correspondence: effa@usm.my (S.Z.N.E.); norazmimn@usm.my (M.N.N.)
}

Received: 21 June 2018; Accepted: 28 August 2018; Published: 5 November 2018

check for updates

\begin{abstract}
Immunomodulation, as a means of immunotherapy, has been studied in major research and clinical laboratories for many years. T-Regulatory (Treg) cell therapy is one of the modulators used in immunotherapy approaches. Similarly, nuclear receptor peroxisome proliferator activated receptor gamma (PPAR $\gamma$ ) has extensively been shown to play a role as an immuno-modulator during inflammation. Given their mutual roles in downregulating the immune response, current study examined the influence of PPAR $\gamma$ ligands i.e., thiazolidinedione (TZD) class of drugs on Forkhead Box P3 (Foxp3) expression and possible crosstalk between PPAR $\gamma$ and nTreg cells of Non-Obese Diabetes (NOD) and Non-Obese Diabetes Resistant (NOR) mice. Results showed that TZD drug, ciglitazone and natural ligand of PPAR $\gamma$ 15d-prostaglandin downregulated Foxp3 expression in activated nTreg cells from both NOD and NOR mice. Interestingly, addition of the PPAR $\gamma$ inhibitor, GW9662 further downregulated Foxp3 expression in these cells from both mice. We also found that PPAR $\gamma$ ligands negatively regulate Foxp3 expression in activated nTreg cells via PPAR $\gamma$-independent mechanism(s). These results demonstrate that both natural and synthetic PPAR $\gamma$ ligands capable of suppressing Foxp3 expression in activated nTreg cells of NOD and NOR mice. This may suggest that the effect of PPAR $\gamma$ ligands in modulating Foxp3 expression in activated nTreg cells is different from their reported effects on effector T cells. Given the capability to suppress Foxp3 gene, it is possible to be tested as immunomodulators in cancer-related studies. The co-lateral use of PPAR $\gamma$ ligands in nTreg cells in inducing tolerance towards pseudo-self antigens as in tumor microenvironment may uphold beneficial outcomes.
\end{abstract}

Keywords: T-Regulatory cells; immune regulation; Foxp3; PPAR $\gamma$; autoimmune diabetes; NOD mouse; thiazolidinediones; ciglitazone; immunomodulator

\section{Introduction}

Over the past two decades since the identification of naturally-occurring $\mathrm{CD} 44^{+} \mathrm{CD} 25^{+} \mathrm{Foxp}^{+}$ regulatory T cells (nTreg), there has been intense research in delineating the immunobiology of nTreg cells in physiological and pathological conditions [1]. The master regulator in nTreg cells is the transcription factor, Forkhead box P3 (Foxp3), which plays an important role in the development and function of these cells [2,3]. Foxp3 is expressed in the thymus by nTreg cells [4,5] and is transiently expressed by peripheral $\mathrm{CD} 4^{+} \mathrm{CD} 25^{-}$conventional $\mathrm{T}$ cells (iTreg) [5]. In pathological conditions such as 
in autoimmune disorders, the recognition of self-tissues by auto-reactive $\mathrm{T}$ cells leads to the destruction of host tissues or organs. The immunosuppressive role of nTreg cells prevents such destruction from occurring by establishing peripheral self-tolerance toward these auto-reactive T cells [5]. This will thus hinder the development of debilitating autoimmune diseases from occurring. Hence mutation of Foxp3 gene results in the loss of immunoregulatory function of nTreg cells, predisposing the hosts towards autoimmune responses [3,4].

It is well established that Peroxisome Proliferator-Activated Receptor $\gamma$ (PPAR $\gamma$ ) activation is capable of inducing immunodownregulatory responses [6-9]. The ability of PPAR $\gamma$ in inducing anti-inflammatory responses in immune cells has been put forth. The activation of PPAR $\gamma$ by their ligands has been shown to downregulate the clonal expansion of activated T effector (Teff) cells [10]. PPAR $\gamma$ ligands such as the thiazolidinediones (TZDs) class of drugs alleviated adverse autoimmune conditions in allergic reactions and inflammatory bowel disease (IBD) [11,12]. In addition, PPAR $\gamma$ ligands have been shown to ameliorate multiple sclerosis $[13,14]$. The anti-inflammatory effect of 15d-prostaglandin-J2 (15d-PGJ2), a potent PPAR $\gamma$ ligand, significantly inhibited the activation of enchephalitogenic $\mathrm{T}$ cells and protected the development of encephalomyelitis in experimental autoimmune encephalomyelitis (EAE) [14]. The immunoregulatory function of PPAR $\gamma$ ligands may however act via PPAR $\gamma$-dependent or -independent mechanisms [15]. The PPAR $\gamma$ ligand, pioglitazone, reduces allergic rhinitis in mice via PPAR $\gamma$-dependent mechanism [16], while 15d-PGJ2 induces apoptosis in both $\mathrm{T}$ lymphocytes and Jurkat $\mathrm{T}$ cells via the activation of mitochondrial apoptotic pathway [17]. The correlation between PPAR $\gamma$ polymorphism with the increased risk of asthma in humans indicates that the role of PPAR $\gamma$ in anti-inflammatory reaction occurs at the gene expression level [18]. However, the possible mechanism of immunomodulation by PPAR $\gamma$ in nTreg cells is poorly understood. Therefore, this study was conducted to examine the possible crosstalk between immunoregulatory properties of nTreg cells and PPAR $\gamma$ in the murine autoimmune model of Non-Obese Diabetes (NOD) mice. We also included normal control strain of the autoimmune mouse model, Non-Obese diabetic resistant (NOR) mice.

\section{Experimental Section}

\subsection{Mice}

Eight-week old female NOD and NOR mice were purchased from The Jackson Laboratory (Bar Harbour, ME, USA). The mice were maintained in the animal facilities under specific pathogen-free conditions in accordance with the guidelines and regulations of the Universiti Sains Malaysia and used at 12-week of age. Peripheral blood glucose levels were measured every week. Any NOD mice with peripheral glucose level of $12 \mathrm{mmol} / \mathrm{L}$ and above for two consecutive weeks were considered as diabetic NOD and will be sacrificed for the study. All experimental protocols were approved by the Universiti Sains Malaysia (USM) Animal Ethics Committee (approval number: USM/Animal Ethics Approval/2009/(43 [132]).

\subsection{Antibodies and Reagents}

Mouse nTreg cells were isolated from spleen tissues of NOD and NOR mice by magnetic separation. Briefly, $\mathrm{CD}^{+}$cells were purified by negative and positive isolations using MACS $\mathrm{CD} 4{ }^{+} \mathrm{CD} 25^{+}$Treg isolation kit (Miltenyi Biotec, Cologne, Germany). Isolated CD4 ${ }^{+} \mathrm{CD} 25^{+}$Treg cells were then stained with phycoerythrin (PE)-anti mouse CD4, fluorescein isothiocyanate (FITC)-anti mouse CD25 and allophycocyanin (APC)-anti Foxp3 mAbs to determine cell purity using the fluorescence-activated cell sorting (FACS) Canto flow cytometer (BD Biosciences, Franklin Lakes, NJ, USA). Fixation and permeabilization of cells were prepared from BD Pharmingen ${ }^{\mathrm{TM}}$ Transcription Factor Buffer Set. Fix/Perm 1X working solution was freshly prepared from 1 part of 4 X Fix/Perm buffer mixed well with 3 parts of diluent buffer and kept in dark at $4{ }^{\circ} \mathrm{C}$ until used. Working solution of $1 X$ Perm/Wash buffer was diluted 1 part of 5X Perm/Wash buffer with 4 parts of sterile deionized 
water and kept at $4{ }^{\circ} \mathrm{C}$. Labelled cells comprised $\geq 90 \%$ with $>80 \%$ Foxp $3^{+} \mathrm{CD} 4^{+} \mathrm{CD} 25^{+}$cells were obtained. The isolated $\mathrm{CD} 4^{+} \mathrm{CD} 25^{+} \mathrm{Foxp}^{+}$cells were used as nTreg cells and were cultured in RPMI 1640 supplemented with 10\% FBS (Thermo Fischer Scientific, Waltham, MA, USA), 5 ng/mL rmIL-2, $10 \mathrm{mM}$ HEPES, $500 \mu \mathrm{L}$ antibiotic stock solution containing $100 \mathrm{U} / \mathrm{mL}, 100 \mu \mathrm{g} / \mathrm{mL}$ streptomycin and $10 \mu \mathrm{M} \beta$-mercaptoethanol (Gibco BRL, Grand Island, NY, USA). IL-2 was purchased from BD Biosciences (New Jersey, NJ, USA), ciglitazone and 15d-PGJ2 were purchased from Cayman Chemicals (Ann Arbor, MI, USA) and GW9662 was purchased from Sigma-Aldrich (St. Louis, MO, USA).

\subsection{Flow Cytometry Analysis}

The expression of CD4 and CD25 surface markers and intracellular Foxp3 was evaluated using PE-conjugated anti-CD4, FITC-conjugated anti-CD25 and APC-conjugated anti-Foxp3. The phosphorylated ZAP-70 and STAT-5 proteins were evaluated by using FITC-conjugated anti-phosphorylated ZAP-70 and FITC-conjugated anti-phosphorylated STAT-5 antibodies and was assessed on FACS Canto Flow cytometer (BD Biosciences, NJ, USA). Mouse PE-and APC-conjugated IgG1 and FITC-conjugated IgG2a were used as isotype controls. Doublet discrimination and annexin analyses were not performed in this experiment due to low cell numbers and proliferation analysis was done using Carboxyfluorescein succinimidyl ester (CFSE) dye staining to observe expansion capacity of cultured cells (data not shown).

\subsection{Total RNA Isolation, cDNA Synthesis and Real-Time PCR for the Detection of PPAR $\gamma$ and Foxp3}

Total RNA was extracted using the RNAeasy Mini kit (Qiagen, Germany) and subjected to cDNA synthesis using cDNA first strand synthesis (Qiagen, Germany). To quantify the concentration of unknown transcripts, a standard curve for PPAR $\gamma$ was generated. Briefly, a serial dilution of the target PPAR $\gamma$ DNA plasmid concentration, corresponding to 101 to 107 copy numbers was prepared and amplified to generate standard curves. Polymerase Chain Reaction (PCR) was performed using primers for PPAR $\gamma$ (forward: 5'-GCG GCT GAG AAA TCA CGT TC-3', Reverse: 5'-TTA AAA ATG TCC TGA ATA TCA GTG GTT C-3' , Probe: 5'-GCT TCT TTC AAA TCT TGT CTG TCA CAC AGT-3'). Foxp3 gene with accession number AF277992.1 was selected from the National Center for Biotechnology Information (NCBI) database and quantified using TaqMan ${ }^{\circledR}$ Gene Expression assay for Foxp3 gene (assay ID Mm00475162_m1). The copy numbers for unknown samples were determined by extrapolating the data from these standard curves. The PPAR $\gamma$ expression level was reported as the number of mRNA transcripts per $\mu \mathrm{g}$ of total RNA (transcript/ $\mu \mathrm{g}$ ). Data were analyzed using the ABI prism software (Applied Biosystem, Foster City, CA, USA).

\subsection{PPAR $\gamma$-PPRE Binding Activity}

$\operatorname{PPAR} \gamma$ activation was measured by its binding to the response element, Peroxisome-proliferator response elements (PPRE). This was measured by using ligand binding assay of PPAR $\gamma$ transcription factors (Cayman Chemical, Ann Arbor, MI, USA). The nuclear proteins of treated and untreated cells were extracted using the Nuclear Extraction kit (Cayman Chemical, Ann Arbor, MI, USA). A 96 well-plate, pre-coated with immobilized PPRE was used to detect the binding of activated PPAR $\gamma$ in the nuclear extract from samples. Using rabbit polyclonal primary antibody against PPAR $\gamma$ and goat anti-rabbit secondary antibody-conjugated with horseradish peroxidase (HRP), the plate was prepared for detection of colorimetric signal changes using enzyme-linked immunosorbent assay (ELISA) plate reader at $450 \mathrm{~nm}$.

\subsection{Signaling Pathways Modulation by PCR Array}

This experiment was conducted using real-time PCR and the data obtained were analyzed via close system software PCR Array Data Analysis Software provided by SA Biosciences (Qiagen, Germany). This software extrapolates the data based on $C t$ values to report the fold differences between treated groups and untreated group using the $2^{-\Delta \Delta C t}$ formula. Total RNA was extracted from nTreg cells of NOD and NOR mice treated or untreated with PPAR $\gamma$ ligands. RNA extraction was performed 
using RNAeasy Mini kit (Qiagen, Germany) and subjected to cDNA synthesis using cDNA first strand synthesis (Qiagen, Germany). The cDNA was then used to perform Qiagen Mouse Signal Transduction Pathway Finder RT2 Profiler PCR Array (catalog no. PAMM-014), (Qiagen, Germany). Two Arrays were performed for each mouse strain. Changes in cycle threshold $(\Delta C \mathrm{t})$ for each gene were obtained by subtracting the mean threshold cycle $(\mathrm{Ct})$ of the housekeeping genes (Gusb, HPRT, Hsp90ab1, Gapdh and $\beta$-Actin) from the threshold cycle value of the gene. The fold regulation was calculated relative to the untreated group when genes that showed more than 5 -fold difference were determined as have been upregulated while those less than 0.2 -fold considered as downregulated.

\subsection{Statistical Analyses}

Data from experimental analyses were presented as the mean of triplicates with standard error mean (mean \pm SEM). The data were statistically analyzed using the Minitab ${ }^{\circledR}$ 16.1.0 software (MiniTab Inc., State College, PA, USA). The comparison between control and treated groups was tested for significance using one-way analysis of variance (ANOVA) test. Post-Hoc comparison test was performed to compare significant levels between treated groups. $p$ value of less than $0.05(p<0.05)$ is considered significant.

\section{Results}

\subsection{Efficiency of $C D 4^{+} C D 25^{+}$Foxp $3^{+} n$ Treg Cells Isolation from NOD and NOR Mice}

$\mathrm{CD} 4{ }^{+}$cells with $\mathrm{CD} 25^{\text {high }}$ and $\mathrm{CD} 25^{\text {intermediate }}$ were considered as $\mathrm{CD} 4{ }^{+} \mathrm{CD} 25^{+}$cells. Enriched $\mathrm{CD} 4^{+} \mathrm{CD} 25^{+}$homogenous cells were isolated for downstream experiments. The purity of nTreg cells isolated from splenocytes of NOD and NOR mouse strains was measured by flow cytometry (Figure 1). The percentage of $\mathrm{CD} 4^{+} \mathrm{CD} 25^{+}$cells from both strains was $>90 \%$ and was further stained with anti-Foxp3 antibodies to measure $\mathrm{CD} 4{ }^{+} \mathrm{CD} 25^{+}$cells that constitutively expressed Foxp3 protein. Figure 1d showed histogram of these cells expressing high intensity of Foxp3 protein with fluorescent intensity detected between $10^{2}$ to $10^{3}$ as compared to isotype control.

\subsection{Expression of Foxp3 in nTreg Cells of NOD and NOR Mice}

The influence of selected PPAR $\gamma$ ligands on Foxp3 in activated nTreg cells was tested by measuring the levels of Foxp3 mRNA expression in nTreg cells of NOD and NOR mice. These cells were treated with 15d-PGJ2 and ciglitazone in the presence or absence of the PPAR $\gamma$ inhibitor, GW9662. A group of untreated activated nTreg cells from both NOD and NOR mice was used as control for each of the mouse strain. The results obtained from the correlation analyses in NOD and NOR mice are shown in Figure 2. In both mouse strains, activated nTreg cells treated with ciglitazone expressed lower levels of Foxp3 mRNA compared to untreated group $(p<0.01)$. In both strains, the addition of GW9662, further reduced Foxp3 expression in these cells compared to ciglitazone-treated cells $(p<0.05)$. In NOD mice, treatment with 15d-PGJ2 significantly reduced the expression of Foxp3 mRNA in activated nTreg cells in comparison to untreated cells $(p<0.01)$. Similarly, Foxp3 expression in activated nTreg cells of NOR mice was undetectable after treatment with 15d-PGJ2 in comparison to untreated cells $(p<0.01)$.
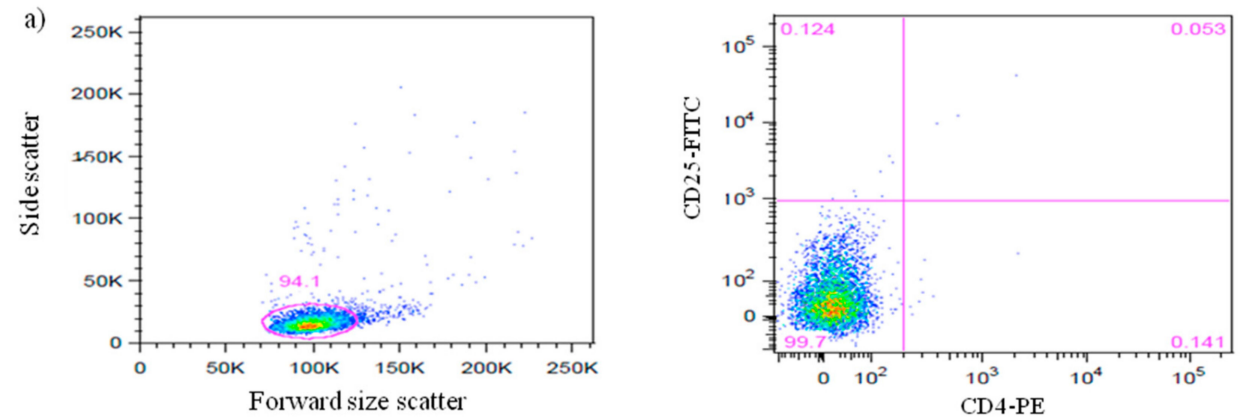

Figure 1. Cont. 

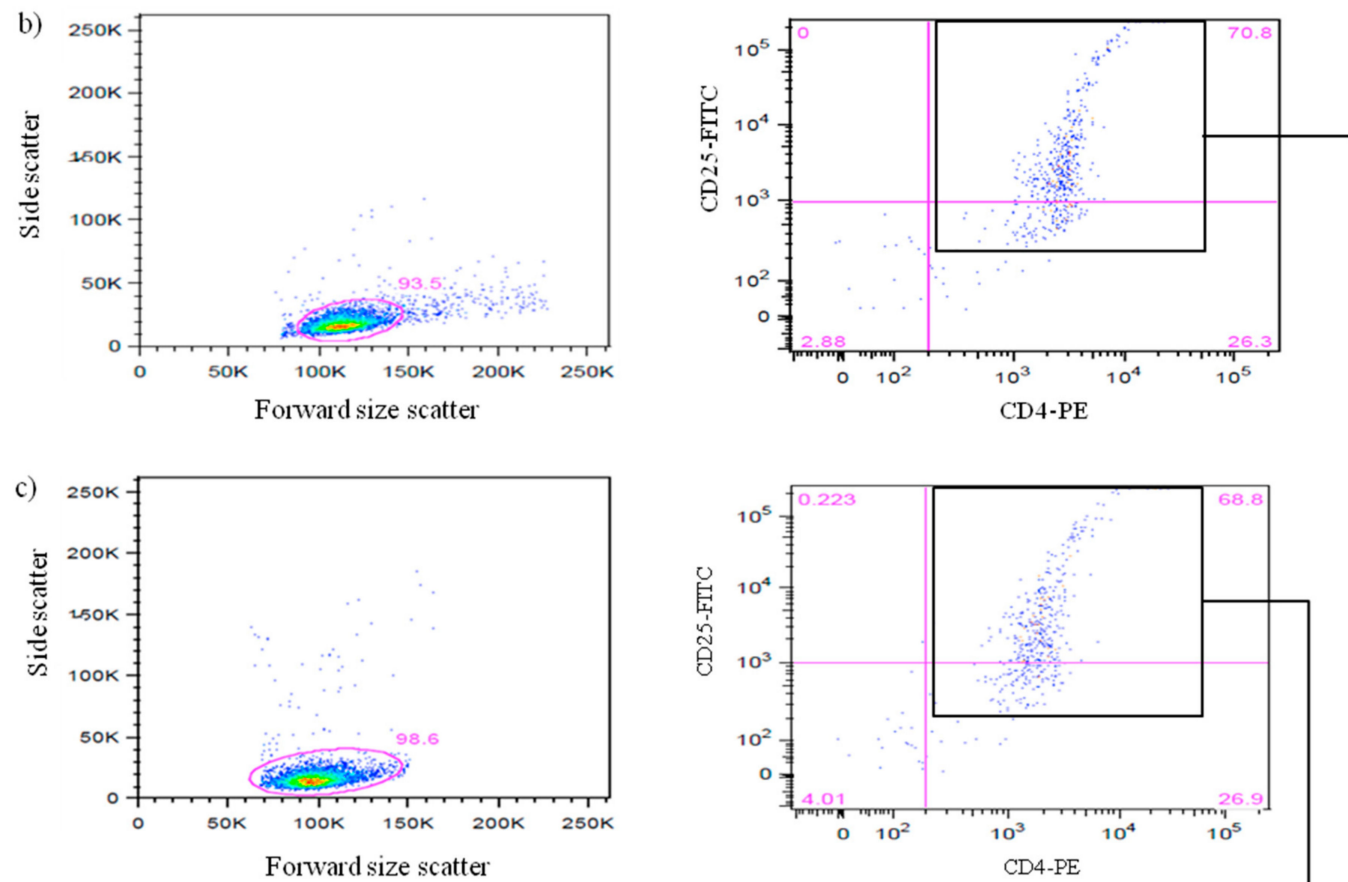

d)

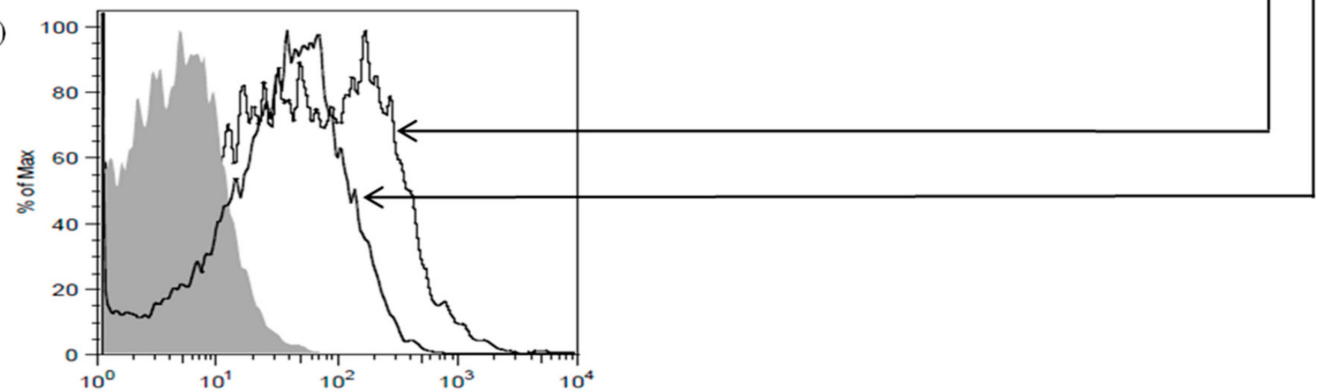

Figure 1. Efficiency of $\mathrm{CD} 4{ }^{+} \mathrm{CD} 25^{+}$expressing Foxp3+ Treg isolation from Non-Obese Diabetes (NOD) and Non-Obese Diabetes Resistant (NOR) mice splenocytes. (a) Dot plot representing lymphocytes stained with IgG1-PE and IgG2a-FITC isotype controls. (b) Dot plot shows lymphocytes stained with PE-conjugated rat anti-mouse CD4 and FITC-conjugated rat anti-mouse CD25 from NOD mice. (c) Dot plot shows lymphocytes stained with PE-conjugated rat anti mouse CD4 and FITC-conjugated rat anti-mouse CD25 from NOR mice. (d) Histograms show the expression of Foxp3 ${ }^{+}$cells gated on $\mathrm{CD}^{+} \mathrm{CD}^{2} 5^{+}$populations from NOR mice (arrow) and NOD mice (arrow), compared with the isotype control (filled grey). Data shown are representative of three independent experiments. $(n=3$ mice/experiment).

\subsection{Binding Activity between PPAR $\gamma$ and PPRE in nTreg Cells of NOD and NOR Mice}

The specific sequence for PPAR $\gamma$ at the binding domain of DNA is known as PPRE. Activation of PPAR $\gamma$ via its ligand results in its translocation into the nucleus and the binding of the activated receptor to PPRE, at the DNA binding domain after heterodimerization with retinoid $X$ receptor (RXR) [19]. Thus, we investigated the binding activity of PPAR $\gamma$ and PPRE in activated nTreg cells from NOD and NOR mice following treatment with their ligands, with or without the PPAR $\gamma$ inhibitor. For this analysis, we postulated that following treatment with PPAR $\gamma$ ligands i.e., ciglitazone and 15d-PGJ2, activated PPAR $\gamma$ would bind to PPRE. Our result showed that there was negligible binding activity between PPAR $\gamma$ and PPRE in activated nTreg cells from both NOD and NOR mice after the respective treatments (Figure 3). This suggests that the activity of PPAR $\gamma$ ligand treatment of nTreg cells is independent of PPRE binding. On the other hand, adipose tissue nuclear lysate which was used as a positive control showed strong binding with the plate-bound PPRE. 


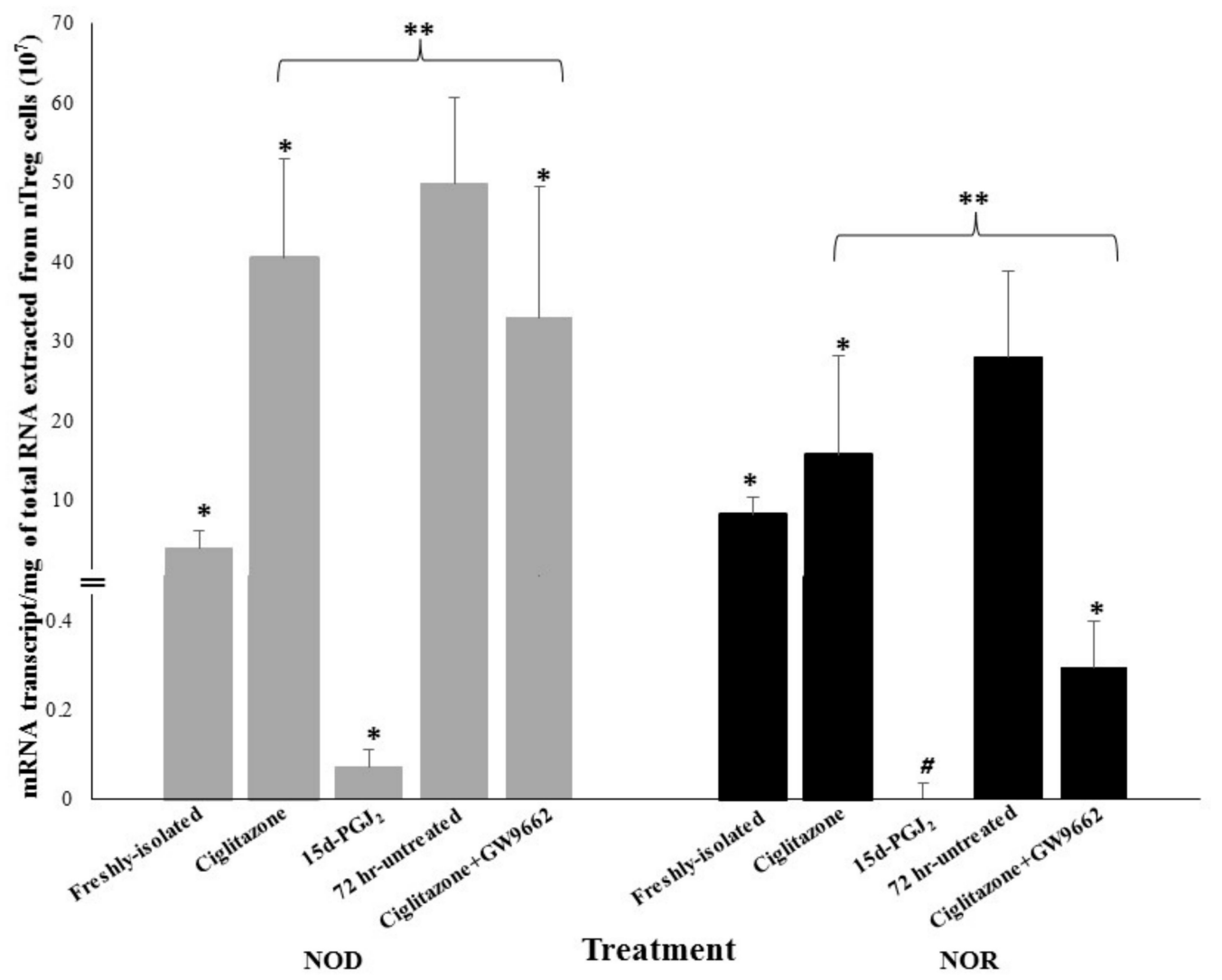

Figure 2. Foxp3 mRNA expression levels in nTreg cells from NOD and NOR mice following various treatment after $72 \mathrm{~h}$ culture. The grey bars represent Foxp3 mRNA transcripts from NOD mice while the black bars represent NOR mice. In NOD and NOR mice, the presence of ciglitazone significantly suppressed Foxp3 expression level in activated nTreg cells compared to untreated group. Moreover, the addition of GW9662 further downregulated Foxp3 level in these cells from both strains compared to untreated cells $(p<0.01)$ and ciglitazone-treated cells $(p<0.05)$. In NOD mice, Foxp3 expression in $15 \mathrm{~d}-\mathrm{PGJ}_{2}$-treated activated nTreg cells was suppressed compared to untreated cells $(p<0.01)$. Data are expressed as the amount of mRNA transcripts per $\mu \mathrm{g}$ of total RNA. This experiment was repeated twice and the graph was plotted based on the mean transcript values \pm SEM. Statistical analysis was performed using One-way ANOVA. Post-hoc comparison was performed to identify the significance between treated samples ( $n=4$ mice/experiment). ${ }^{*} p<0.01$, sample groups vs. untreated group. ${ }^{* *} p<0.05$, ciglitazone-treated group vs. ciglitazone + GW9662-treated group. ${ }^{*} p<0.01$, sample groups vs. untreated group. ${ }^{* *} p<0.05$, ciglitazone-treated group vs. ciglitazone + GW9662-treated group. \# the expression level was undetectable.

\subsection{Phosphorylation Levels of ZAP-70 \& STAT-5 Transduction Proteins}

In newly activated T cells, phosphorylation of ZAP-70 initiates the activation of phosphorylation cascades in proximal intracellular signaling to propagate downstream responses. In order to examine the effect of PPAR $\gamma$ ligands on the proximal and distal signaling pathways in nTreg cells, phosphorylation levels of ZAP-70 proteins were studied in activated nTreg cells of NOD and NOR mice. Following $72 \mathrm{~h}$ incubation with the PPAR $\gamma$ ligands, nTreg cells were stained with phosphorylated-ZAP-70 conjugated antibodies. Untreated nTreg cells were included as controls and isotype control was used to set the marker for fluorochrome staining. There was no significant difference in the levels of ZAP-70 phosphorylation in either treated or untreated cells of NOD or NOR mice (Figure 4). These findings may suggest that ZAP-70 phosphorylation is not involved in the activation of nTreg cells of NOD and NOR mice. 


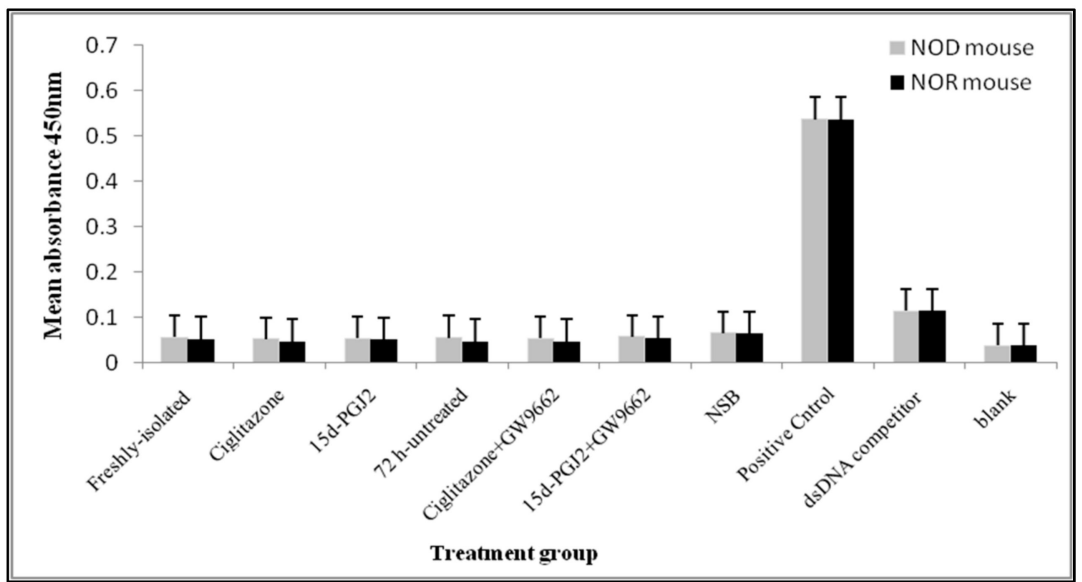

Figure 3. The binding activity between PPAR $\gamma$ and PPRE in nTreg cells nuclear protein lysates from NOD and NOR mice. The bar graphs show mean absorbance for each indicated treatment performed in duplicate. PPAR $\gamma$ double-stranded DNA (dsDNA) competitors were added onto dsDNA competitor wells while non-specific binding (NSB) wells were added with buffer without positive control or samples. Blank wells contained only buffer. This experiment was repeated twice and error bars represent mean $\pm \operatorname{SEM}(n=3$ mice/experiment).

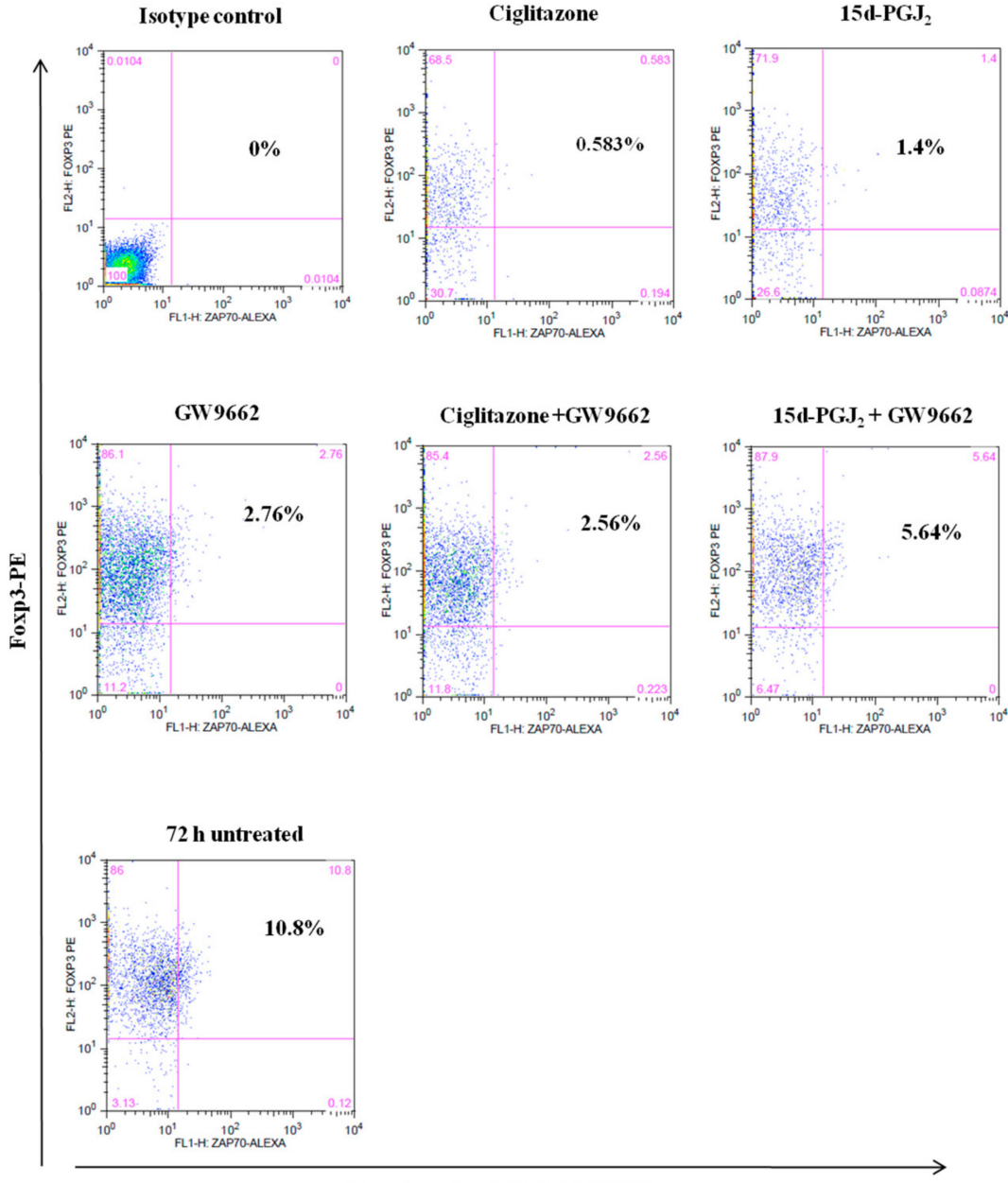

Phosphorylated ZAP 70-ALEXA

(a)

Figure 4. Cont. 


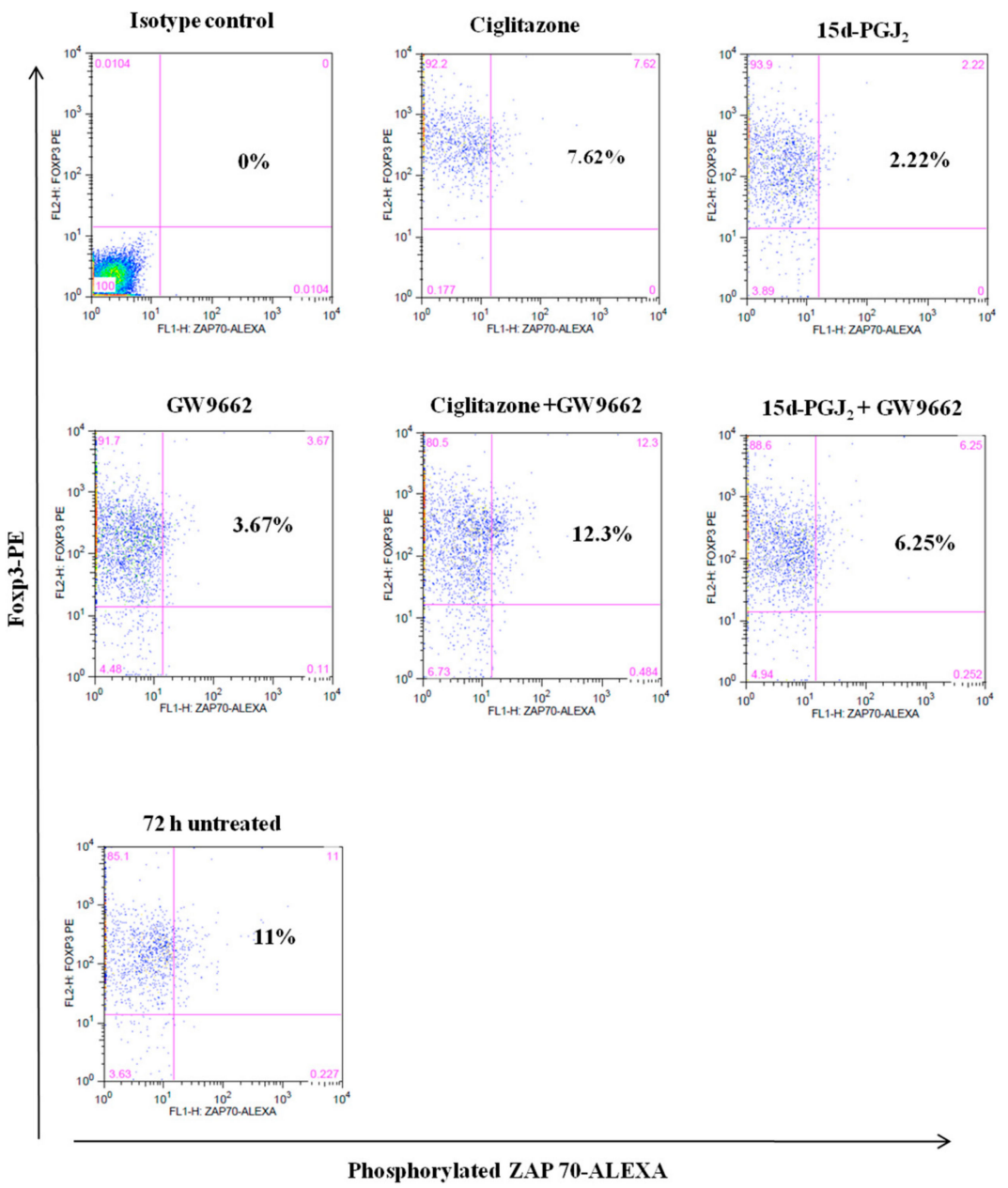

(b)

Figure 4. The expression of phosphorylated ZAP-70 in nTreg cells of (a) NOD and (b) NOR mice following various treatment after $72 \mathrm{~h}$ culture. Dot plot shows the levels of phosphorylated ZAP-70 in activated nTreg cells as indicated by Foxp3 expression. ZAP-70 phosphorylation was measured in nTreg cells treated with ciglitazone, $15 \mathrm{~d}-\mathrm{PGJ}_{2}$, GW9662, combination of ciglitazone + GW9662, and combination of $15 \mathrm{~d}-\mathrm{PGJ}_{2}+$ GW9662. 72 h-untreated cells were assigned as control group. Data shown are representative of two independent experiments. ( $n=2$ mice/experiment).

In T-lymphocytes, IL-2 binding to IL-2R will activate STAT- 5 transcription factor, which in turn activate a set of genes that are involved in T cell development and inflammation [20]. On the other hand, in nTreg cells, the activation of STAT- 5 by IL-2 signaling is important in Foxp3 expression and survival of nTreg cells [21]. Upon IL2-IL2R binding, activation of STAT- 5 by phosphorylation is initiated to affect downstream signaling components such as JAK/STAT signaling [22]. Therefore, IL-2/STAT-5 signaling pathway is an important pathway in nTreg cells as it directly correlates with Foxp3 expression. Intervention of this pathway by PPAR $\gamma$ ligands may indicate the association between PPAR $\gamma$ and nTreg cells at the IL-2/JAK-STAT level. Following $72 \mathrm{~h}$ incubation with the PPAR $\gamma$ ligands, these cells were stained with phosphorylated-STAT- 5 conjugated antibodies. Similarly, untreated nTreg cells were included as controls and isotype control was used to set the marker for fluorochrome staining. Activated nTreg cells of NOD and NOR mice demonstrated constitutive phosphorylation of STAT-5 with no significant influence from PPAR $\gamma$ ligand treatment (Figure 5). Our current results may suggest that JAK/STAT signaling is required in activated nTreg cells for downstream events since we recorded 
high levels of phosphorylated STAT- 5 in these cells. In addition, there was a negative association between STAT5 activation and PPAR $\gamma$ in nTreg cells of both NOD and NOR mice.
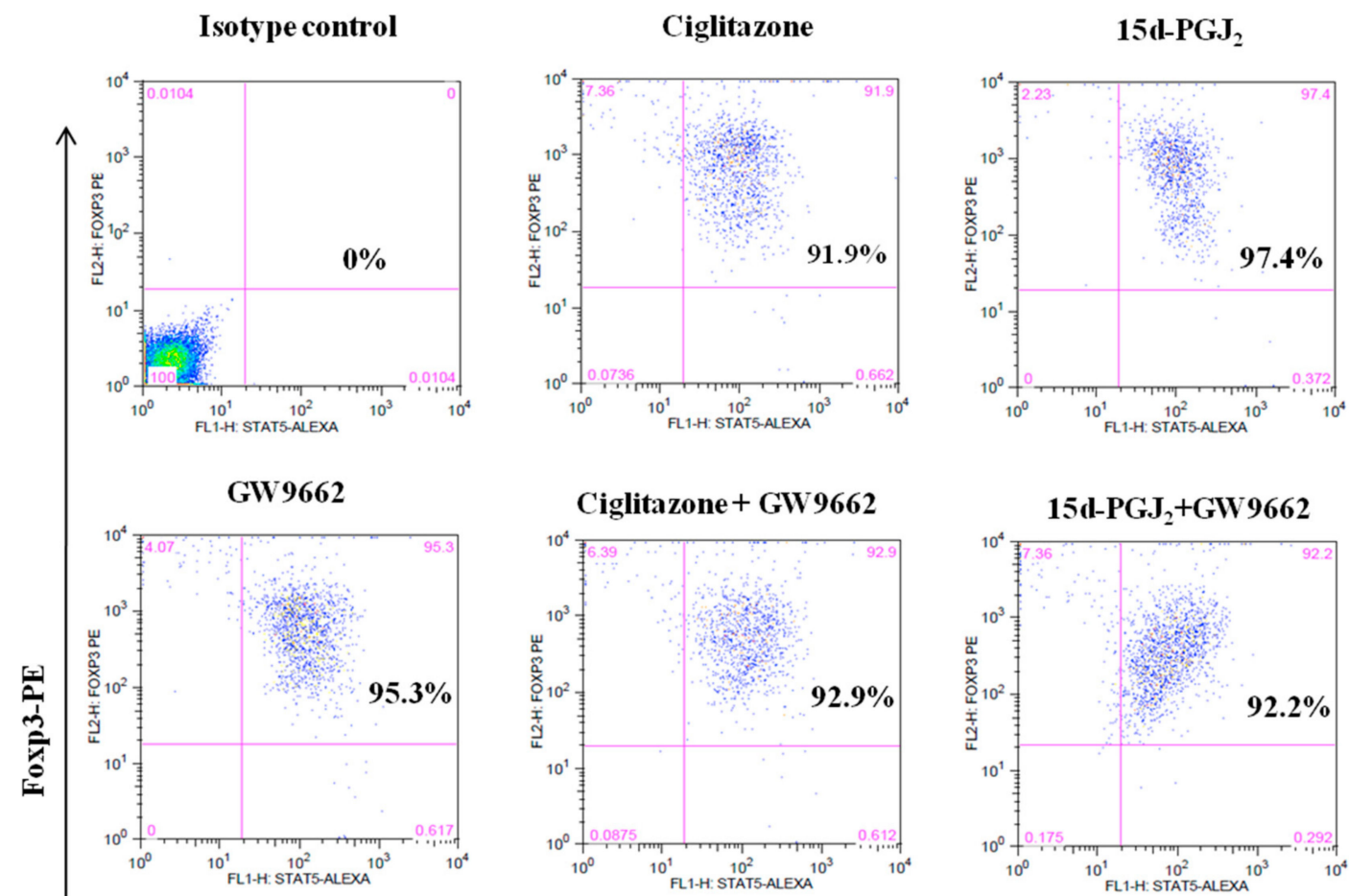

\section{Ciglitazone + GW9662}
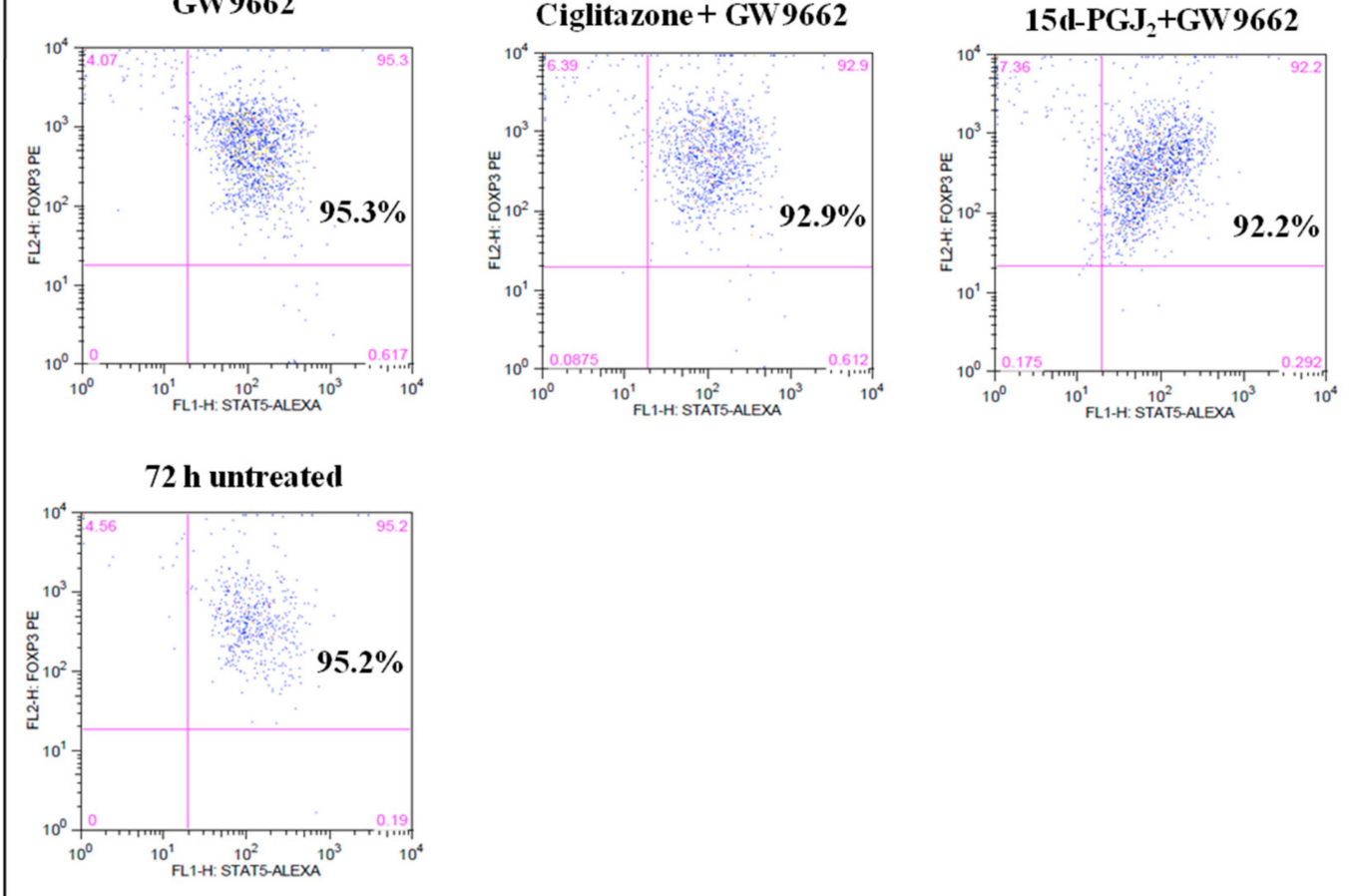

Phosphorylated STAT 5-ALEXA

(a)

Figure 5. Cont. 


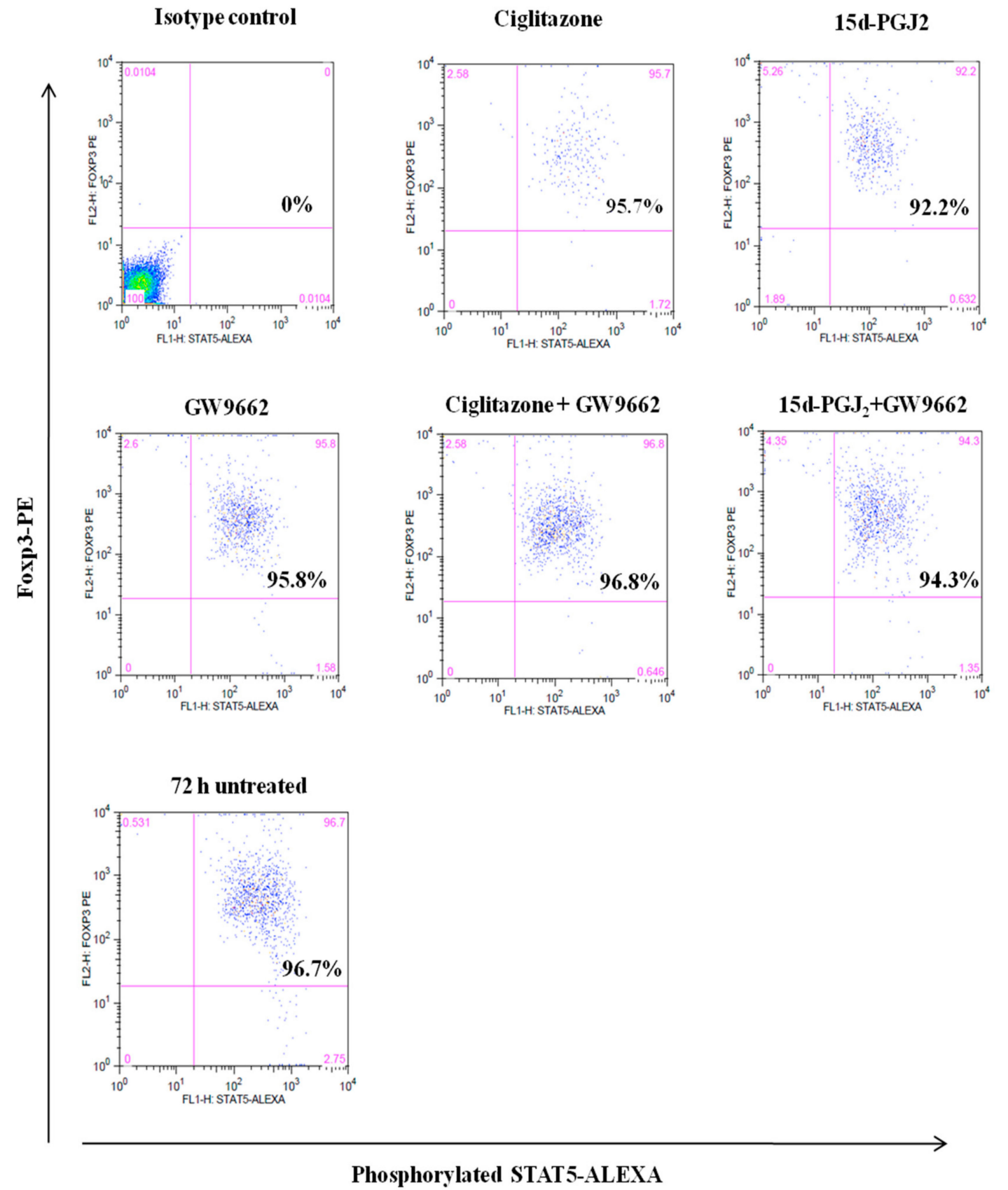

(b)

Figure 5. The expression of phosphorylated STAT-5 in activated nTreg cells of (a) NOD and (b) NOR mice following various treatment after $72 \mathrm{~h}$ culture. Dot plot shows the levels of phosphorylated STAT-5 in nTreg cells. STAT-5 phosphorylation level was measured in activated nTreg cells treated with ciglitazone, 15d-PGJ 2 , GW9662, combination of ciglitazone + GW9662, and combination of 15d-PGJ $2+$ GW9662. 72 h-untreated group was assigned as control group. Data shown are representative of two independent experiments ( $n=2$ mice/experiment).

3.5. Differential Gene Expression Involved in Signal Transduction Pathways in nTreg Cells of NOD and NOR Mice

In order to assess the possible crosstalk between PPAR $\gamma$ and signaling pathways in nTreg cells, we examined the modulation of selected gene expression in these cells following treatment with PPAR $\gamma$ ligands. By using the Signal Transduction PathwayFinder ${ }^{\mathrm{TM}}$ array, we analyzed 84 important genes 
responsive to 18 different signal transduction pathways. Out of the 18 signaling pathways, 4 signaling pathways that are relevant in immune cells were chosen.

The fold change cut-off value for gene expression was determined at $>$ five-fold change in order to arbitrarily assign meaningful biological differences between expressed genes. This result is hoped to provide some information on biologically relevant genes in nTreg cells and their association with PPAR $\gamma$. Tables S1-S4 depict the differentially regulated pathway-related target genes in NOD and NOR mice following treatment with PPAR $\gamma$ ligands. In NOD mice, most of inflammatory-related pathways were downregulated in PPAR $\gamma$ ligand-treated nTreg cells. In NOR mice, a few genes including $c d k n 1 a$, ccl20, il2ra, lta, nfkbia, nos 2 and tank genes were upregulated in PPAR $\gamma$ ligand-treated nTreg cells and these genes are known to be involved in pro- inflammatory related pathways. Furthermore, $c d 5$ gene that is responsible for the expression of CD5 antigen on cell surface was upregulated in ciglitazone-treated nTreg cells from NOR mice.

\section{Discussion}

Since both PPAR $\gamma$ and Foxp3 are involved in immune suppression, we investigated whether there is cross-talk between these transcription factors in nTreg cells. To provide insight into the functional aspect of these cells, we utilized the autoimmune diabetic, NOD mouse model, to further dissect the interactions between these transcription factors. PPAR $\gamma$ ligands have been shown to induce anti-inflammatory responses in autoimmune models [23-25]. However, whether PPAR $\gamma$ modulate the function of nTreg cells during autoimmune conditions has not been described.

Our analysis showed that PPAR $\gamma$ ligands downregulated Foxp3 expression in nTreg cells of both the autoimmune NOD as well as its control NOR mouse models. To further characterize whether this effect occurs via the PPAR $\gamma$ activation pathway, we treated the nTreg cells with its inhibitor, GW9662 and analyzed the binding of PPAR $\gamma$ to its response element. Our current data demonstrated that both ciglitazone and 15d-PGJ2 promoted the downregulation of Foxp3 expression independently of PPAR. The addition of GW9662 did not abrogate the effect of the PPAR $\gamma$ ligand, but instead further suppressed Foxp3 expression in nTreg cells of both NOD and NOR mice. This finding is in agreement with a previous report by Lei et al. [26] who showed that in human peripheral blood mononuclear cells, PPAR $\gamma$ agonists do not alter Foxp3 expression in nTreg cells and iTreg cells via PPRE. However, whether this effect is primarily due to the direct interaction between PPAR $\gamma$ and Foxp3 or secondary to interaction with other protein molecules require further investigation. The synergistic effect of PPAR $\gamma$ ligands and GW9662 have been demonstrated in growth inhibition of breast cancer cells [27] and suppression of IL-2 production in T-helper cells [28]. In fact, treatment with GW9662 alone was able to reduce IL-2 production in T-helper cells and Jurkat T-cell lines, suggesting that GW9662 has an intrinsic inhibitory property [28,29]. The reasons for these observations are however still unclear.

Our findings are contrary to previous reports that showed ciglitazone induced Foxp3 expression in in vitro generation of iTreg cells from PPAR $\gamma$-deleted mouse model [30,31]. Since previous studies identified the role of these ligands on iTreg cells thus may contribute to discrepancy with current findings. In fact, previous study also reported that the suppressive capacity of nTreg cells is not affected by PPAR $\gamma$ ligands, an indication that PPAR $\gamma$ agonists neither modify the Foxp3 expression nor the suppressive function of nTreg cells in healthy animals [31]. This is in line with our data that showed Foxp3 protein levels in nTreg cells-treated with ciglitazone is not significantly suppressed as apposed mRNA levels that are significantly reduced following ligands treatment. The first report on the effect of PPAR $\gamma$ ligands on nTreg cells was demonstrated in a GHVD model [31] where co-transfer of wild type nTreg cells with ciglitazone positively promote survival of these mice compared to PPAR $\gamma$-deleted nTreg cells. This suggests that PPAR $\gamma$-expressing nTreg cell is important in mediating ciglitazone effect in vivo [31]. However, whether this effect is mediated by the level of Foxp3 or suppressive function in these cells was not studied. We speculate that the interaction between PPAR $\gamma$ and nTreg cells in in vivo setting may involve multiple players that results in the enhancement of nTreg cell function and that PPAR $\gamma$ ligands act differently in iTreg and nTreg cells respectively. Our study also demonstrated that, 
there was no significant PPAR $\gamma$-PPRE interaction in PPAR $\gamma$ ligand-treated nTreg cells of both NOD and NOR mice, further indicating that the observed effect occurred independent of PPAR $\gamma$ activation.

PPAR $\gamma$ ligands negatively affect proinflammatory cytokine production by inhibiting the transcription factors AP-1, NF- $\kappa \beta$, NFAT and STATs in CD4 ${ }^{+} \mathrm{T}$ cells [32-34]. On the other hand, Foxp3 expression requires binding of AP-1, NF- $\kappa \beta$ and NFAT at the promoter and enhancer sites of nTreg cells [35-38]. Thus, the current findings suggest that PPAR $\gamma$ ligands may modulate Foxp3 expression in nTreg cells by interfering with the activation of these transcription factors which may in turn modulate the function of Foxp3 in nTreg cells. As a result, Foxp3 expression in nTreg cells is attenuated. We proposed that the effect is mediated by transrepression regulation of PPAR $\gamma$ ligands, which is differently described from the transcriptional suppression/repression mechanism [39,40].

We also examined whether this effect is due to PPAR $\gamma$ interference on the proximal or distal signaling components of nTreg cells by measuring the phosphorylation levels of ZAP-70 and STAT-5. The phospohorylation of ZAP-70 results in activation of downstream signaling pathways [41] while STAT-5 signaling is required for nTreg cell function and survival [21]. Therefore, we analyzed the level of phosphorylation of these mediators following treatment with PPAR $\gamma$ ligands. Our current study showed that PPAR $\gamma$ ligands did not modify the phosphorylation levels of ZAP-70 or STAT-5 in nTreg cells from both mice models. This finding suggests that these ligands do not suppress Foxp3 expression in nTreg cells from both mice models by modulating ZAP-70 and STAT-5 signaling pathways. These findings are consistent with a previous report by [42] where they elucidated that the activation of ZAP-70 is extremely low in $\mathrm{CD}^{+} \mathrm{CD} 25^{+} \mathrm{Foxp}^{+}$cells. Meanwhile, although not significantly different, STAT5 phosphorylation levels were reduced in nTreg cells from NOD mice following treatment with ciglitazone, and further reduced when PPAR $\gamma$ inhibitor were added. Conversely, $15 \mathrm{~d}-\mathrm{PGJ}_{2}$ induced STAT5 phosphorylation in nTreg cells from NOD mice and addition of PPAR $\gamma$ inhibitor reversed the effect. As opposed to NOD mice, nTreg cells showed the opposite effect of PPAR $\gamma$ ligands in NOR mouse model. Addition of both ligands reduced STAT5 phosphorylation and was slightly opposed by its inhibitor, GW9662. These findings may suggest the different regulation of PPAR $\gamma$ ligands in nTreg cells from NOD and NOR mice models. Previous study reported that PPAR $\gamma$ do not hinder STAT-5 phosphorylation but rather affect the downstream signaling of the growth hormone- activated STAT- 5 activation [43].

Next, we investigated the differential effect of PPAR $\gamma$ ligands in these cells from NOD and NOR mice by examining any alterations of the relevant genes in signaling pathways using the PCR Array technology. While ciglitazone moderately induced myc and odc gene expression levels in nTreg cells of NOD and NOR mice, we also observed downregulation of pro- and anti-inflammatory pathway-related genes in PPAR $\gamma$ ligand-treated nTreg cells of NOD mice. The stimulation of myc gene indicates a common response to a vast group of substances that elicit phosphoinositate and activate PKC signaling pathway [44] whereas activation of odc1 gene promotes cell survival activities [45]. The activation of PKC pathway by ciglitazone is related on the survival of these cells in both mouse strains in vitro since PKC pathway activation in nTreg cells is canonical for cell proliferation and survival [46]. Furthermore, recent study showed that Foxp3 protein can regulate T cell metabolism by suppressing myc gene in T cell [47]. According to Angelin et al. (2017), Foxp3 suppresses myc-dependent genes and thus regulate Treg cell metabolism to adapt in low-glucose/high-lactate rich environments [47]. In the current findings, addition of ciglitazone inhibits Foxp3 expression in nTreg cells and induces myc expression in ciglitazone-treated nTreg cells in NOD and NOR mice. This may suggest that ciglitazone capable of reversing Foxp3 expression by upregulating myc expression in vitro.

Furthermore, we observed 12 target genes related to TGF- $\beta$, NF- $\kappa \beta$, and NFAT signaling pathways in PPAR $\gamma$ ligand-treated nTreg cells from NOR mice model. TGF- $\beta$ and p53-related gene, $c d k n 1 a$ that encodes protein cyclin-dependent kinase inhibitor was slightly upregulated in nTreg cells following treatment with ciglitazone, but not $15 \mathrm{~d}-\mathrm{PGJ}_{2}$. The upregulation may be due to cross-linkage with p53-dependent pathway since $c d k n 1 a$ gene is under joint control of TGF- $\beta$ and p53 signaling [48]. Also, overlapping cellular function by both components may indicate that they have potential 
convergence points in their signaling pathways [49]. Also, ciglitazone induced NF- $\kappa \beta$ pathway-related genes i.e., il2ra and $n f-k b i a$, but not $15 \mathrm{~d}-\mathrm{PGJ}_{2}$ in NOR mice. Other genes, such as ccl20, lta and tank were slightly upregulated in ciglitazone-treated cells. These data may suggest that ciglitazone restricts NF- $\kappa \beta$ activation by upregulating $n f-k b i a$ expression, at the same time, inducing expression of CD25 molecules by upregulating il-2ra gene in nTreg cells from healthy NOR mice. The expression of this gene is also regulated by PKC signaling. Thus, upregulation of $i l-2 r a$ gene induced by ciglitazone in nTreg cells is possibly via PKC dependent-NF- $\kappa \beta$ pathway, since NF- $\beta$ activation is preceded by PKC signaling. We also recorded that ciglitazone moderately upregulated NFAT-related target gene, cd5 in nTreg cells from NOR mice. This gene is responsible to encode for CD5 molecules on nTreg cell surfaces, responsible for suppressive function [50] thus this may correspond to the default function of nTreg cells as immunosuppressor of autoreactive immune cells in normal condition.

In addition, we observed seven similar target genes that were downregulated in both NOD and NOR nTreg cells following treatment with PPAR $\gamma$ ligands. These target genes are nab2 gene of MAPK pathway and ei24 and igfbp3 genes of NFAT pathway. MAPK-related target gene, nab2 is associated with antigen recognition in $\mathrm{CD}^{+} \mathrm{T}$ lymphocytes [51]. Overall, the downregulation of proand anti-inflammatory related target genes by PPAR $\gamma$ ligands in NOD and NOR nTreg cells may suggest the correlation with Foxp3 expression in these cells in autoimmune diabetic NOD mice as well as healthy control NOR mice. Therefore, this data help in narrowing down possible regulatory molecules responsible on PPAR $\gamma$-Foxp3 crosstalk in activated nTreg cells

Lastly, we would like to discuss on the possible technical variation in our laboratory settings. As this study isolated $\mathrm{CD} 4^{+} \mathrm{CD} 25^{+} \mathrm{Foxp}^{+}$cells using magnetic cell sorting method, thus we believe this could also contributed to the discrepancies in the findings. As some of the previous studies performed cell sorting by using automated method, this could also possible to differentially affect the cell phenotype and genotype when compared to magnetic method. Furthermore, since current study did not perform viability and doublet discrimination for flow cytometry analyses, we postulated that some of the cells are false positive lead to the impurity in cell isolation but at a manageable level as shown in the dot plot analyses.

\section{Conclusions}

Taken collectively, our current findings demonstrated the negative regulation of PPAR $\gamma$ ligands in inducing Foxp3 expression in nTreg cells of NOD and NOR mouse models. However, the underlying mechanism of Foxp3 suppression was differentially modulated in NOD and NOR nTreg cells. Our data from NOD and NOR mouse models suggest that PPAR $\gamma$ ligands attenuated Foxp3 mRNA expression in TCR-activated nTreg cells via PPAR $\gamma$-independent pathways. Even though it is well-described that PPAR $\gamma$ ligands induce target gene expression via PPAR $\gamma$-dependent manner, it is becoming increasingly clear that PPAR $\gamma$ ligands also mediate the non-genomic PPAR $\gamma$-dependent and -independent manners [52,53]. The non-genomic PPAR $\gamma$ ligands requires activation of PPAR $\gamma$ by its ligands without subsequent DNA-binding of PPAR $\gamma$ [53]. This suggests that there are other possible mechanisms used by these ligands to regulate gene expression in ligand dependent but non PPRE-dependent manner by circumventing the binding to specific response elements in the promoter or enhancer region of target genes [39,40]. We speculate that in NOD nTreg cells, PPAR $\gamma$ ligands reduced Foxp3 expression either via downregulation of multiple target genes in pro-inflammatory pathway related genes. These pro-inflammatory signaling pathways such as NFAT, NK- $\beta$ and PKC are essential for Foxp3 expression in nTreg cells, not for pro-inflammatory cytokine production [32-38]. An extensive analysis on Foxp3 expression in nTreg cells is also required in delineating the regulatory components involved in Foxp3 expression, particularly in committed nTreg cells. Although much remains to be learned about the basis of PPAR $\gamma$ and its ligands on Foxp3 expression in nTreg cells, the current study provided additional information to preliminary relationship between PPAR $\gamma$ ligands and Foxp3 expression thus put forward the redefinition of PPAR $\gamma$ ligands as immune modulators in tumor-associated conditions. In tumor microenvironment, population of Foxp $3^{+}$Treg cells may indicate 
poor prognosis as they provide protection to tumor cells against tumor-infiltrating lymphocytes [54-58]. It is thus instrumental to look further into the potential function of TZD drugs on Foxp3 ${ }^{+}$Treg cells in tumor models as suggested by current study. The co-lateral use of PPAR $\gamma$ ligands in these cells in inducing tolerance towards pseudo-self antigens as in tumor microenvironment may uphold beneficial outcomes.

Supplementary Materials: The following are available online at http:/ /www.mdpi.com/2218-273X/8/4/135/s1, Table S1: Differentially expressed target genes of pathways related to immune cells in ciglitazone-treated nTreg cells from NOD mice, Table S2: Differentially expressed target genes of pathways related to immune cells in prostaglandin $\mathrm{J}_{2}$-treated $\mathrm{nTreg}$ cells from NOD mice, Table S3: Differentially expressed target genes of pathways related to immune cells in ciglitazone-treated nTreg cells from NOR mice, Table S4: Differentially expressed target genes of pathways related to immune cells in prostaglandin $\mathrm{J}_{2}$-treated nTreg cells from NOR mice.

Author Contributions: All authors contributed equally in the design of the study, data collection, data analysis and preparation of the manuscript.

Funding: This study was funded by Research University (Individual) Grant, Universiti Sains Malaysia (1001.PPSK.813063), Scientific Advancement Grant Allocation (SAGA), Akademi Sains Malaysia (304.PPSK.6153003.A118) and Fundamental Research Grant Scheme (FRGS), Ministry of Education Malaysia (203.CIPPT.6711483).

Conflicts of Interest: The authors have no financial conflict of interest.

\section{References}

1. Bettini, M.L.; Vignali, D.A.A. Development of thymically derived natural regulatory T cells. Ann. N. Y. Acad. Sci. 2010, 1183, 1-12. [CrossRef] [PubMed]

2. Fontenot, J.D.; Gavin, M.A.; Rudensky, A.Y. Foxp3 programmes the development and function of $\mathrm{CD} 4^{+} \mathrm{CD} 25^{+}$ Regulatory T-Cells. Nat. Immunol. 2003, 4, 330-336. [CrossRef] [PubMed]

3. Hori, S.; Nomura, T.; Sakaguchi, S. Control of regulatory T cell development by the transcription factor Foxp3. Science 2003, 299, 1057-1061. [CrossRef] [PubMed]

4. Fontenot, J.D.; Rasmussen, J.P.; Williams, L.M.; Dooley, J.L.; Farr, A.G.; Rudensky, A.Y. Regulatory T cell lineage specification by the Forkhead Transcription Factor Foxp3. Immunity 2005, 22, 329-341. [CrossRef] [PubMed]

5. Sakaguchi, S.; Yamaguchi, T.; Nomura, T.; Ono, M. Regulatory T cells and immune tolerance. Cell 2008, 133, 775-787. [CrossRef] [PubMed]

6. Li, M.; Pascual, G.; Glass, C.K. Peroxisome Proliferator-Activated Receptor $\gamma$-dependent repression of the inducible nitric oxide synthase gene. Mol. Cell. Biol. 2000, 20, 4699-4707. [CrossRef] [PubMed]

7. Rotondo, D.; Davidson, J. Prostaglandin and PPAR control of immune cell function. Immunology 2002, 105, 20-22. [CrossRef] [PubMed]

8. Von Knethen, A.; Soller, M.; Tzieply, N.; Weigert, A.; Johann, A.M.; Jennewein, C.; Kohl, R.; Brune, B. PPAR $\gamma 1$ attenuates cytosol to membrane translocation of PKC $\alpha$ to desensitize monocytes/macrophages. J. Cell. Biol. 2007, 176, 681-694. [CrossRef] [PubMed]

9. Sauter, M.; Kastenmuller, K.; Belling, F.; Wornle, M.; Ladurner, R.; Mussack, T.; Sitte, T. Activation of Peroxisome Proliferator-Activated Receptor-Gamma by glitazones reduces the expression and release of monocyte chemoattractant protein-1 in human mesothelial cells. Mediat. Inflamm. 2012, 2012, 2176960. [CrossRef] [PubMed]

10. Clark, R.B.; Bishop, B.D.; Estrada, H.D.; Hla, T.; Puddington, L.; Padula, S.J. The nuclear receptor PPAR $\gamma$ and immunoregulation: PPAR $\gamma$ mediates inhibition of helper T cell responses. J. Immunol. 2000, 164, 1364-1371. [CrossRef] [PubMed]

11. Hammad, H.; de Heer, H.J.; Soullie, T.; Angeli, V.; Trottein, F.; Hoogsteden, H.C.; Lambrecht, B.N. Activation of Peroxisome Proliferator-Activated Receptor- $\gamma$ in Dendritic Cells inhibits the development of eosinophilic airway inflammation in a mouse model of asthma. Am. J. Pathol. 2004, 164, 263-271. [CrossRef]

12. Hontecillas, R.; Horne, W.T.; Climent, M.; Guri, A.J.; Evans, C.; Zhang, Y.; Sobral, B.W.; Bassaganya-Riera, J. Immunoregulatory mechanisms of macrophage PPAR- $\gamma$ in mice with experimental inflammatory bowel disease. Mucosal Immunol. 2011, 4, 304-313. [CrossRef] [PubMed] 
13. Klotz, L.; Schmidt, M.; Giese, T.; Sastre, M.; Knolle, P.; Klockgether, T.; Heneka, M.T. Proinflammatory stimulation and pioglitazone treatment regulate Peroxisome Proliferator-Activated Receptor $\gamma$ levels in peripheral blood mononuclear cells from healthy controls and multiple sclerosis patients. J. Immunol. 2005, 175, 4948-4955. [CrossRef] [PubMed]

14. Racke, M.K.; Gocke, A.R.; Muir, M.; Diab, A.; Drew, P.D.; Lovett-Racke, A.E. Nuclear Receptors and Autoimmune disease: The Potential of PPAR Agonists to Treat Multiple Sclerosis. J. Nutr. 2006, 136, 700-703. [CrossRef] [PubMed]

15. Yamashita, M. PPAR $\alpha / \gamma$ independent Effects of PPAR $\alpha / \gamma$ Ligands on Cysteinyl Leukotriene production in mast cells. PPAR Res. 2008, 2008, 293538. [CrossRef] [PubMed]

16. Wang, W.; Zhu, Z.; Zhu, B.; Ma, Z. Peroxisome Proliferator-Activated Receptor- $\gamma$ Agonist Induces Regulatory T Cells in a Murine Model of Allergic Rhinitis. Otolaryngol. Head Neck Surg. 2011, 144, 506-513. [CrossRef] [PubMed]

17. Nencioni, A.; Lauber, K.; Grunebach, F.; Van Parijs, L.; Denzlinger, C.; Wesselborg, S.; Brossart, P. Cyclopentenone prostaglandins induce lymphocyte apoptosis by activating the mitochondrial apoptosis pathway independent of external death receptor signaling. J. Immunol. 2003, 171, 5148-5156. [CrossRef] [PubMed]

18. Oh, S.-H.; Park, S.-M.; Lee, Y.H.; Cha, J.Y.; Lee, J.-Y.; Shin, E.K.; Park, J.-S.; Park, B.-L.; Shin, H.D.; Park, C.-S. Association of peroxisome proliferator-activated receptor-gamma gene polymorphisms with the development of asthma. Resp. Med. 2009, 103, 1020-1024. [CrossRef] [PubMed]

19. IJpenberg, A.; Jeannin, E.; Wahli, W.; Desvergne, B. Polarity and specific sequence requirements of Peroxisome Proliferator-activated Receptor (PPAR)/retinoid X receptor heterodimer binding to DNA: A functional analysis of the malic enzyme gene PPAR response element. J. Biol. Chem. 1997, 272, 20108-20117. [CrossRef] [PubMed]

20. Gilmour, K.C.; Pine, R.; Reich, N. Interleukin 2 activates STAT5 transcription factor (mammary gland factor) and specific gene expression in T lymphocytes. Proc. Natl. Acad. Sci. USA 1995, 92, 10772-10776. [CrossRef] [PubMed]

21. Burchill, M.A.; Goetz, C.A.; Prylic, M.; O’Neil, J.J.; Harmon, I.R.; Bensinger, S.J.; Turk, L.A.; Brennan, P.; Jameson, S.C.; Farrar, M.A. Distinct effects of STAT5 activation on CD4 ${ }^{+}$and CD8 ${ }^{+}$T cell homeostasis: Development of $\mathrm{CD} 4{ }^{+} \mathrm{CD} 25^{+}$Regulatory T cells versus CD8 ${ }^{+}$Memory T cells. J. Immunol. 2003, 171, 5853-5864. [CrossRef] [PubMed]

22. Passerini, L.; Allan, S.E.; Battaglia, M.; Di Nunzio, S.; Alstad, A.N.; Levings, M.K.; Roncarolo, M.G.; Bacchetta, R. STAT5-signaling cytokines regulate the expression of FOXP3 in $\mathrm{CD} 4{ }^{+} \mathrm{CD} 25^{+}$regulatory T cells and $\mathrm{CD}^{+}{ }^{+} \mathrm{CD} 25^{-}$effector T cells. Int. Immunol. 2008, 20, 421-431. [CrossRef] [PubMed]

23. Feinstein, D.L.; Galea, E.; Gavrilyuk, V.; Brosnan, C.F.; Whitacre, C.C.; Dumitrescu-Ozimek, L.; Landreth, G.E.; Pershadsingh, H.A.; Weinberg, G.; Heneka, M.T. Peroxisome proliferator-activated receptor- $\gamma$ agonists prevent experimental autoimmune encephalomyelitis. Ann. Neurol. 2002, 51, 694-702. [CrossRef] [PubMed]

24. Welch, J.S.; Ricote, M.; Akiyama, T.E.; Gonzalez, F.J.; Glass, C. KPPAR $\gamma$ and PPAR $\delta$ negatively regulate specific subsets of lipopolysaccharide and IFN- $\gamma$ target genes in macrophages. Proc. Natl. Acad. Sci. USA 2003, 100, 6712-6717. [CrossRef] [PubMed]

25. Diab, A.; Deng, C.; Smith, J.D.; Hussain, R.Z.; Phanavanh, B.; Lovett-Racke, A.E.; Drew, P.D.; Racke, M.K. Ligands for the peroxisome proliferator-activated receptor- $\gamma$ and the retinoid X receptor exert additive anti-inflammatory effects on experimental autoimmune encephalomyelitis. J. Neuroimmunol. 2004, 148, 116-126. [CrossRef] [PubMed]

26. Lei, J.; Hitoshi, H.; Takuya, M.; Masaki, Y. Peroxisome Proliferator-Activated Receptor $\alpha$ and $\gamma$ agonist together with TGF- $\beta$ convert human $\mathrm{CD} 4^{+} \mathrm{CD} 25^{-}$T cells into functional Foxp3 ${ }^{+}$regulatory cells. J. Immunol. 2010, 201, 7186-7198. [CrossRef] [PubMed]

27. Seargent, J.M.; Yates, E.A.; Gill, J. HGW9662, a potent antagonist of PPAR $\gamma$, inhibits growth of breast tumour cells and promotes the anticancer effects of the PPAR $\gamma$ agonist rosiglitazone, independently of PPAR $\gamma$ activation. Br. J. Pharmacol. 2004, 143, 933-937. [CrossRef] [PubMed]

28. Jaudszus, A.; Lorkowski, S.; Gruen, M.; Roth, A.; Jahreis, G. Limited Applicability of GW9662 to Elucidate PPARg-mediated Fatty Acid Effects in Primary Human T-helper Cells. Int. J. Inflamm. 2014, 2014, 149628. [CrossRef] [PubMed] 
29. Raman, P.; Kaplan, B.L.F.; Kaminski, N. E15-Deoxy- $\Delta^{12,14}$-Prostaglandin $\mathrm{J}_{2}$-Glycerol, a Putative Metabolite of 2-Arachidonyl Glycerol and a Peroxisome Proliferator-Activated Receptor $\gamma$ Ligand, Modulates Nuclear Factor of Activated T Cells. J. Pharm. Exp. Ther. 2012, 342, 816-926. [CrossRef] [PubMed]

30. Hontecillas, R.; Bassaganya-Riera, J. Peroxisome proliferator-Activated Receptor $\gamma$ is required for regulatory $\mathrm{CD}^{+} \mathrm{T}$ cell mediated Protection against colitis. J. Immunol. 2007, 178, 2940-2949. [CrossRef] [PubMed]

31. Wohlfert, E.A.; Nichols, F.C.; Nevius, E.; Clark, R.B. Peroxisome Proliferator-activated Receptor- $\gamma$ is and immunoregulation: Enhancement of regulatory T-cells through PPAR $\gamma$-dependant and independant mechanism. J. Immunol. 2007, 178, 4129-4135. [CrossRef] [PubMed]

32. Yang, X.Y.; Wang, L.H.; Chen, T.; Hodge, D.R.; Resau, J.H.; DaSilva, L.; Farrar, W.L. Activation of human T lymphocytes is inhibited by Peroxisome Proliferator-activated Receptor $\gamma$ (PPAR $\gamma$ ) Agonists: PPAR $\gamma$ co-association with transcription factor NFAT. J. Biol. Chem. 2000, 275, 4541-4544. [CrossRef] [PubMed]

33. Delerive, P.; Fruchart, J.C.; Staels, B. Peroxisome proliferator-activated receptors in inflammation control. J. Endocrinol. 2001, 169, 453-459. [CrossRef] [PubMed]

34. Cunard, R.; Ricote, M.; DiCampli, D.; Archer, D.; Clay, K.; Daniel, A.; Glass, C.K.; Kelly, C.J. Regulation of cytokine expression by ligands of Peroxisome Proliferator Activated Receptors. J. Immunol. 2002, 168, 2795-2802. [CrossRef] [PubMed]

35. Wang, P.; Anderson, P.O.; Chen, S.; Paulsson, K.M.; Sjogren, H.-O.; Li, S. Inhibition of the transcription factors AP-1 and NF- $\mathrm{kB}$ in CD4 T cells by peroxisome proliferator-activated receptor $\gamma$ ligands. Int. Immunopharmacol. 2001, 1, 803-812. [CrossRef]

36. Mantel, P.-Y.; Ouaked, N.; Ruckert, B.; Karagiannidis, C.; Welz, R.; Blaser, K.; Schmidt-Weber, C.B. Molecular mechanisms underlying FOXP3 induction in human T cells. J. Immunol. 2006, 176, 3593-3602. [CrossRef] [PubMed]

37. Wu, Y.; Borde, M.; Heissmeyer, V.; Feuerer, M.; Lapan, A.D.; Stroud, J.C.; Bates, D.L.; Guo, L.; Han, A.; Ziegler, S.F.; et al. FOXP3 controls Regulatory $\mathrm{T}$ cell function through cooperation with NFAT. Cell 2006, 126, 375-387. [CrossRef] [PubMed]

38. Long, M.; Park, S.-G.; Strickland, I.; Hayden, M.S.; Ghosh, S. Nuclear Factor-kB Modulates Regulatory T Cell Development by Directly Regulating Expression of Foxp3 Transcription Factor. Immunity 2009, 31, 921-931. [CrossRef] [PubMed]

39. Pascual, G.; Fong, A.L.; Ogawa, S.; Gamliel, A.; Li, A.C.; Perissi, V.; Rose, D.W.; Willson, T.M.; Rosenfeld, M.G.; Glass, C.K. A SUMOylation-dependent pathway mediates transrepression of inflammatory response genes by PPAR $\gamma$. Nature 2005, 437, 759. [CrossRef] [PubMed]

40. Ricote, M.; Glass, C.K. PPARs and molecular mechanisms of transrepression. Biochim. Biophys. Acta Mol. Cell Biol. Lipids 2007, 1771, 926-935. [CrossRef] [PubMed]

41. Weil, R.; Israel, A. Deciphering the pathway from the TCR to NF-кB. Cell Death Differ. 2006, 13, 826-833. [CrossRef] [PubMed]

42. Carson, B.D.; Ziegler, S.F. Impaired T cell receptor signaling in Foxp3 ${ }^{+}$CD4 ${ }^{+}$T Cells. Ann. N. Y. Acad. Sci. 2007, 1103, 167-178. [CrossRef] [PubMed]

43. Shipley, J.M.; Waxman, D.J. Down-Regulation of STAT5b Transcriptional Activity by Ligand-Activated Peroxisome Proliferator-Activated Receptor- $\alpha$ and $-\gamma$. Mol. Pharmacol. 2003, 64, 355-364. [CrossRef] [PubMed]

44. Coughlin, S.R.; Lee, W.M.F.; Williams, P.W.; Giels, G.M.; Williams, L.T. c-myc gene expression is stimulated by agents that activate protein kinase $C$ and does not account for the mitogenic effect of PDGF. Cell 1985, 43, 243-251. [CrossRef]

45. Pendeville, H.; Carpino, N.; Marine, J.-C.; Takahashi, Y.; Muller, M.; Martial, J.A.; Cleveland, J.L. The ornithine decarboxylase gene is essential for cell survival during early murine development. Mol. Cell. Biol. 2001, 21, 6549-6558. [CrossRef] [PubMed]

46. Hickman, S.P.; Yang, J.; Thomas, R.M.; Wells, A.D.; Turka, L.A. Defective activation of Protein Kinase C and Ras-ERK pathways limits IL-2 production and proliferation by CD4 ${ }^{+} \mathrm{CD} 25^{+}$Regulatory T Cells. J. Immunol. 2006, 177, 2186-2194. [CrossRef] [PubMed]

47. Angelin, A.; Gil-de-Gomez, L.; Dahiya, S.; Jiao, J.; Guo, L.; Levine, M.H.; Wang, Z.; Quinn, W.J., III; Kopinski, P.K.; Wang, L.; Akimova, T. Foxp3 reprograms T cell metabolism to function in low-glucose, high lactate environments. Cell Metab. 2017, 25, 1282-1293. [CrossRef] [PubMed] 
48. Cordenonsi, M.; Dupont, S.; Maretto, S.; Insinga, A.; Imbriano, C.; Piccolo, S. Links between tumor suppressors. Cell 2003, 113, 301-314. [CrossRef]

49. Elston, R.; Inman, G.J. Crosstalk between p53 and TGF- $\beta$ Signaling. J. Signal Transduct. 2012, $2012,294097$. [CrossRef] [PubMed]

50. Dasu, T.; Qualls, J.E.; Tuna, H.; Raman, C.; Cohen, D.A.; Bondada, S. CD5 plays an inhibitory role in the suppressive function of murine $\mathrm{CD} 4{ }^{+} \mathrm{CD} 25^{+}$Treg cells. Immunol. Lett. 2008, 119, 103-113. [CrossRef] [PubMed]

51. Collins, S.; Lutz, M.A.; Zarek, P.E.; Anders, R.A.; Kersh, G.J.; Powell, J.D. Opposing regulation of T cell function by Egr-1/NAB2 and Egr-2/Egr-3. Eur. J. Immunol. 2008, 38, 528-536. [CrossRef] [PubMed]

52. Gardner, O.S.; Shiau, C.-W.; Chen, C.-S.; Graves, L.M. Peroxisome Proliferator-activated Receptor $\gamma$-independent Activation of p38 MAPK by Thiazolidinediones involves calcium/calmodulin-dependent Protein Kinase II and Protein Kinase R: Correlation with endoplasmic reticulum stress. J. Biol. Chem. 2005, 280, 10109-10118. [CrossRef] [PubMed]

53. Endo, Y.; Suzuki, M.; Yamada, H.; Horita, S.; Kunimi, M.; Yamazaki, O.; Shirai, A.; Nakamura, M.; Iso-O, N.; Li, Y.; et al. Thiazolidinediones enhance sodium-coupled bicarbonate absorption from renal proximal tubules via PPAR $\gamma$-dependent non-genomic signaling. Cell Metab. 2011, 13, 550-561. [CrossRef] [PubMed]

54. Siddiqui, S.A.; Frigola, X.; Bonne-Annee, S.; Mercader, M.; Kuntz, S.M.; Krambeck, A.E.; Sengupta, S.; Dong, H.; Cheville, J.C.; Lohse, C.M.; et al. Tumor-infiltrating Foxp3-CD4+CD25+ T cells predict poor survival in renal cell carcinoma. Clin. Cancer Res. 2007, 13, 2075-2081. [CrossRef] [PubMed]

55. Ladanyi, A.; Mohos, A.; Somlai, B.; Liszkay, G.; Gilde, K.; Fejos, Z.; Gaudi, I.; Timar, J. FOXP3 ${ }^{+}$cell density in primary tumor has no prognostic impact in patients with cutaneous malignant melanoma. Pathol. Oncol. Res. 2010, 16, 303-309. [CrossRef] [PubMed]

56. Mougiakakos, D.; Johansson, C.C.; Trocme, E.; All-Ericsson, C.; Economou, M.A.; Larsson, O.; Seregard, S.; Kiessling, R. Intratumoral forkhead box P3-positive regulatory T cells predict poor survival in cyclooxygenase-2-positive uveal melanoma. Cancer 2010, 116, 2224-2233. [CrossRef] [PubMed]

57. Shah, W.; Yan, X.; Jing, L.; Zhou, Y.; Chen, H.; Wang, Y. A reversed CD4/CD8 ratio of tumor-infiltrating lymphocytes and a high percentage of $\mathrm{CD} 4\left({ }^{+}\right) \mathrm{FOXP} 3\left({ }^{+}\right)$regulatory $\mathrm{T}$ cells are significantly associated with clinical outcome in squamous cell carcinoma of the cervix. Cell Mol. Immunol. 2011, 8, 59-66. [CrossRef] [PubMed]

58. Gerber, A.L.; Münst, A.; Schlapbach, C.; Shafighi, M.; Kiermeir, D.; Hüsler, R.; Hunger, R.E. High expression of FOXP3 in primary melanoma is associated with tumour progression. Br. J. Dermatol. 2014, 170, 103-109. [CrossRef] [PubMed]

(C) 2018 by the authors. Licensee MDPI, Basel, Switzerland. This article is an open access article distributed under the terms and conditions of the Creative Commons Attribution (CC BY) license (http://creativecommons.org/licenses/by/4.0/). 